\title{
Characterization of bio-physical features in Thalawila fishing ground, North-western coast of Sri Lanka
}

\author{
H.B. Jayasiri", K. Arulananthan and S.U.P. Jinadasa \\ National Aquatic Resources Research and Development Agency (NARA), Crow Island, Colombo 15.
}

Revised: 04 March 2014; Accepted: 20 June 2014

\begin{abstract}
Fish aggregation is area specific and strongly links with oceanographic processes and parameters. The sea off Thalawila in the North-western region of Sri Lanka is a major fishing ground particularly for the tuna longline fishery. To study the monsoon response on fishing, environmental data on temperature, conductivity, depth and chlorophyll profiles along with plankton sampling were collected at seven selected locations during the first inter-monsoon and the Northeast monsoon in 2007. The depth of the thermocline was $80-90 \mathrm{~m}$ during the inter-monsoon, and $40-60 \mathrm{~m}$ during the Northeast monsoon. The observations indicated that the depth of the chlorophyll- $a$ maximum varied from $20-80 \mathrm{~m}$. The deepest depth of chlorophyll maxima was found in April. However, there was a broader peak of chlorophyll varying within the depth range of $20-80 \mathrm{~m}$ in January and March. The values of mean phytoplankton and zooplankton abundances of the area were $3273 \pm 771$ and $55.36 \pm 9.82$ indi. $\mathrm{L}^{-1}$, respectively. The chlorophyll- $a$ concentration and the zooplankton density varied as a function of time, but the spatial variability was less significant. The relative compositions of phytoplankton revealed that diatoms dominated with $91 \%$ of the total population followed by $8 \%$ dinoflagellate contribution. The zooplankton analysis indicated the dominance of crustacean larvae comprising about $48.4 \%$ with copepods of about $37.04 \%$. The present analysis indicated that chlorophyll significantly correlated with the phytoplankton and zooplankton density $(p<0.01)$. The findings suggest that thermal structure of the water column and food availability are likely to determine the aggregation of fish off the North-western coast of Sri Lanka.
\end{abstract}

Keywords: Chlorophyll, phytoplankton, thermocline, tuna, zooplankton.

\section{INTRODUCTION}

Coastal fishery strongly links with oceanographic conditions such as sea surface temperature and primary productivity. Understanding upper ocean processes are of great importance in evaluating fish stocks, migration patterns and commercial fishing. Belonging to the genus Thunnus of the family Scombridae, tuna are found in temperate and tropical oceans around the world and account for a major proportion of the world fishery products. It is the propensity of tunas to aggregate into schools, and schools' propensity to aggregate in specific areas, which render this highly mobile species an economically exploitable resource (Sharp, 1978; Sund et al., 1981). Billfishes (i.e., marlins and swordfish) do not form schools, but they do apparently aggregate along specific oceanographic features such as temperature fronts, which can be areas of increased productivity and relatively high prey abundance (Podestá et al., 1993; Olson et al., 1994; Bigelow et al., 1999). Block et al. (1997) stated that yellowfin tuna prefer to spend most of their time just above the thermocline. Moreover, tunas are found in oceanic water masses with oxygen profiles ranging from $6.8-8.6 \mathrm{mg} \mathrm{L}^{-1}$. Although tuna longline fishing gear does not depend on seeing fish at the surface, the gear is deployed such that the hooks target specific depths (Boggs, 1992). Vertical and horizontal distribution of tuna is influenced by temporal and spatial trends in environmental conditions. Among the several factors influencing tuna distribution, temperature and associated features are considered to be the primary determinants. However, studies on migratory behaviour of tunas are in relation to feeding and reproduction.

Different water masses have significant effects on plant and animal life as such water masses carry a wide range of bio-geochemical constituents. Furthermore, the vertical distribution of fish, particularly tuna is influenced by the thermal structure of the water column, the depth of the mixed layer and the strength of the temperature gradient in the thermocline (Kitagawa et al., 2000). 
Biomass of the lower trophic levels directly influence the fish productivity of higher trophic levels in the marine food web. The biomass and distribution of the trophic levels depend on the water quality parameters (i.e. nutrients). Furthermore, the reversal of monsoon currents affects the circulation patterns in the Northern Indian Ocean, which in turn controls the nutrients such as nitrate, nitrite, ammonium and phosphate around Sri Lanka (Shankar et al., 2002). The productivity is also influenced by seasonally varying stability of the water column. The chlorophyll- $a$ distribution, which is an indicator of the primary phytoplankton productivity around Sri Lanka is closely connected to the path of the Southwest monsoon current (SMC) (Vinayachandran et al., 2004). During the first inter-monsoon and the Northeast (NE) monsoon periods, waters around Sri Lanka except in the North show very low surface pigment concentrations (Yapa, 2000). The observed sea-surface temperature distribution generates mini-cold pool (MCP) with comparatively low temperatures $\left(<28{ }^{\circ} \mathrm{C}\right)$ at the south of Indo-Sri Lanka Channel (ISLC) during the winter monsoon. At the same time the north easterly surface winds blow through ISLC with a maximum wind speed of $10 \mathrm{~ms}^{-1}$, which enhances the surface turbulence to lead near surface vertical mixing resulting in cooling. The vertical temperature profiles the designated cooling and deepening of the near-surface isothermal layer from November to January (Rao et al., 2008).

In general, the NE monsoon is considered to be a rather gentle phenomenon; the oceanic circulation is only moderately strong (Wyrtiki, 1973) and the surface flow does not penetrate much below the thermocline to bring up cooler waters from the deep. Thus, favourable wind conditions may result only in occasional weak upwelling along the coast of the study area.

Chlorophyll- $a$ provides a useful estimate of phytoplankton biomass, which reflects the primary productivity. Ocean colour that represents chlorophyll- $a$ can be investigated covering a large area during a short period using satellite images. Nevertheless, the accuracy of chlorophyll data based on remote sensing techniques is low due to high turbidity, cloud cover and small extent of the study area. Therefore ground-truth chlorophyll data is important to obtain the vertical distribution in the ocean (Lorenzen, 1970; Neville \& Gower, 1977). The sub-tropical salinity maximum, which occurs in a thin layer just above the thermocline has been observed to the North and South of the equator (Rao, 1964a). Nearly a $50 \mathrm{~m}$ thick low saline surface layer has been found in the Northern Indian Ocean. The Bay of Bengal water existing in this region has been brought by the prevailing surface currents through the Palk Strait and then the Gulf of Mannar. The thickness of the isothermal layer to the North of equator has been found to vary from $50-70 \mathrm{~m}$ (Rao, 1964b).

The productivity of any aquatic water body depends on the amount of plankton present (Guy, 1992). Zooplankton communities act as a significant food source for a variety of invertebrate and vertebrate predators (Robertson, 1983; Stoecker \& Capuzzo, 1990; Fukami et al., 1999). As such, they play a significant role in energy transfer through the marine pelagic food web and their ecology and dynamics have thus received attention worldwide (Beers \& Stewart, 1971; Godhantaraman \& Uye, 2001).

Tuna make an abrupt transition from a mean deepswimming-depth $(>150 \mathrm{~m}$ ) located in the thermocline $\left(22^{\circ} \mathrm{C}\right)$ to a shallower depth $(50 \mathrm{~m})$ located in the mixed layer $\left(29^{\circ} \mathrm{C}\right)$ where they remain during the whole night in a diurnal cycle (Cayré, 1991). As such, oceanographic data provides a useful tool basis for planning the management of pelagic fish stocks. However, oceanographic data and information is scanty, particularly on the continental shelf of Sri Lanka, except for a few international cruises carried out by the World Ocean Circulation Expedition (WOCE) to collect conductivity, temperature, depth (CTD) and acoustic doppler current profiler (ADCP) data for a better description of the oceanic circulation. Also a few cruises were carried out by the vessles R/V Samudramaru and $\mathrm{S} / \mathrm{V}$ Sayuri around Sri Lanka. The present study deals with the oceanographic characteristics of the coastal waters off Thalawila for providing useful information for planning fisheries management strategies based on oceanographic information.

\section{METHODS AND MATERIALS}

\section{Study area}

The coastal sea off Thalawila in the North-Western region of Sri Lanka is a major fishing ground particularly for the tuna longline fishing (Figure 1). Coastal tuna longline fishing is highly seasonal and relates to the monsoon pattern. The fishing starts in October and continues until April of the following year. The estimated total fish production in the North-Western area was about $1052 \mathrm{t}$ in 2005 and $3313 \mathrm{t}$ in 2006 . The total fishing effort in the North-Western coast was much higher than the NorthEastern coast (Dissanayake et al., 2008).

Tuna longlines operate within $8-15 \mathrm{~km}$ distance from the coast during the North-East monsoon (November February) and the first inter-monsoon (March - April), which are the peak seasons for tuna longline fishing. Therefore, field observations were carried out between 


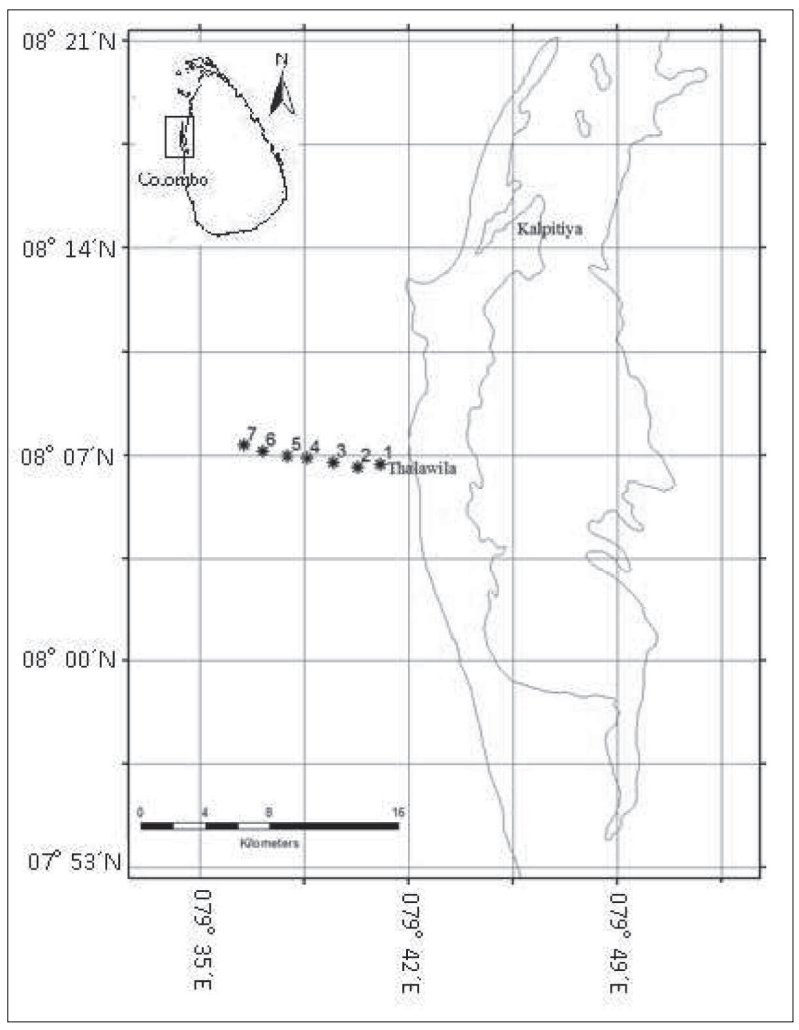

Figure 1: Map of the study area showing sampling locations

January and April and in November 2007 while covering both peak tuna catching seasons. Hydrographic data and water samples were collected at 7 different locations off the coast of Thalawila, Kalpitiya (Figure 1) using a1 5 feet outborad motor (OBM) boat. The length of the survey line was limited to about $10 \mathrm{~km}$ from the coast where the the water depth varies between $500 \mathrm{~m}$ and $2000 \mathrm{~m}$. Water samples were collected for analysis of phytoplankton, zooplankton and chlorophyll in the water column.

\section{Sampling and data collection}

The SBE 19plus Seacat CTD (conductivity - temperature - depth) profiler was used to measure the vertical profiles of conductivity, temperature and pressure (depth). The vertical distribution of chlorophyll- $a$ in the water column was measured using Wetlab fluorescence sensor attached to the CTD profiler. The sampling rate of CTD was $0.25 \mathrm{~Hz}$ (or four samples per second). CTD profiles were collected at each selected location during the study period (Figure 1). The raw data was processed to obtain vertical profiles of salinity, temperature, depth and chlorophyll- $a$ profiles using SeaBird, Processing-Win32 software. Ruttner sampler was used to collect water samples at the depth of $1 \mathrm{~m}$ for surface chlorophyll- $a$ determination. The simpleplankton net(mesh size $100 \mu \mathrm{m})$ was used for zooplankton vertical hauls. The zooplankton samples were preserved in $5 \%$ formalin (Parsons et al., 1984) until laboratory analysis was performed. Surface water samples $(200 \mathrm{~mL})$ were collected using the Ruttner sampler into $250 \mathrm{~mL}$ polythene bottles and immediately fixed with $1 \mathrm{~mL}$ of Lugol's iodine solution (Parsons et al., 1984) for phytoplankton analysis.

\section{Laboratory analysis}

Determination of chlorophyll- $a$ content in waters: Chlorophyll- $a$ was determined by filtering $500 \mathrm{~mL}$ of the water samples using $\mathrm{GF} / \mathrm{C}$ filters (nominal pore size $0.7 \mu \mathrm{m}$ ) under low vacuum. The pigment was extracted with $15 \mathrm{~mL}$ of $90 \%$ acetone and the optical density (absorbance) of the extract was determined with a UV visible spectrophotometer (Shimadzu, Japan) (Richards \& Thompson, 1952; Parsons \& Strickland, 1963). Chlorophyll- $a$ was estimated following Parsons et al. (1984).

Phytoplankton analysis: The water samples preserved with Lugol's solution were analyzed for phytoplankton cell density and taxonomic identification to determine the composition. Supernatant of the preserved water sample was decanted without disturbing the settled cells so that the sample was concentrated to a known volume. One millilitre of this concentrated sample was placed in the Sedgwick rafter cell and numerical abundance, composition and the diversity of phytoplankton were determined under the light microscope at a magnification of $10 \times 10$ (Newell \& Newell, 1963; Robert, 2003; Verlencar \& Somshekar, 2004). The numbers of each taxon were converted to densities, i.e. numbers $\mathrm{m}^{-3}$ (Azeiteiro et al., 2000).

Zooplankton analysis: Zooplankton standing stock was determined by a numerical method. The composition of major taxonomic groups of zooplankton was determined under the light microscope with a magnification of $10 \times 10$. The samples were analyzed for the determination of zooplankton abundance, composition and diversity (Newell \& Newell, 1963; Todd et al., 1991; David et al., 2003; Goswami, 2004). The densities of organisms were expressed as ind. $\mathrm{L}^{-1}$.

\section{RESULTS}

Figures 2(a) and (b) indicate the wind data during January to December 2007. The monsoonal event occurs at the same time in the year with slight changes in some periods. The wind speed varied from $0.08 \mathrm{~ms}^{-1}$ in April to $8.3 \mathrm{~ms}^{-1}$ 
in May and the mean wind speed was $\sim 3 \mathrm{~ms}^{-1}$. The daily averaged wind graphs show a low speed during March, April, October and November, which is relevant to the inter-monsoon season. The speed is higher during the summer monsoon from May to September [Figure 2(a)].

Figure 2(b) illustrates the changes of wind directions in the area where the survey was carried out. The blue dots represent measured directions. The majority of the wind data shows its direction from Southwest towards the land of Sri Lanka during the period of May to September (summer monsoon). However, reversing wind patterns could be observed from January to April and November to December in 2007, which is exactly similar to the expected monsoonal wind patterns.

Vertical variation of salinity, temperature and chlorophyll

Salinity, temperature and chlorophyll varied both spatially (vertically and off-shore) and temporally (Figures 3-5). The vertical variation of salinity in January, March, April (a)

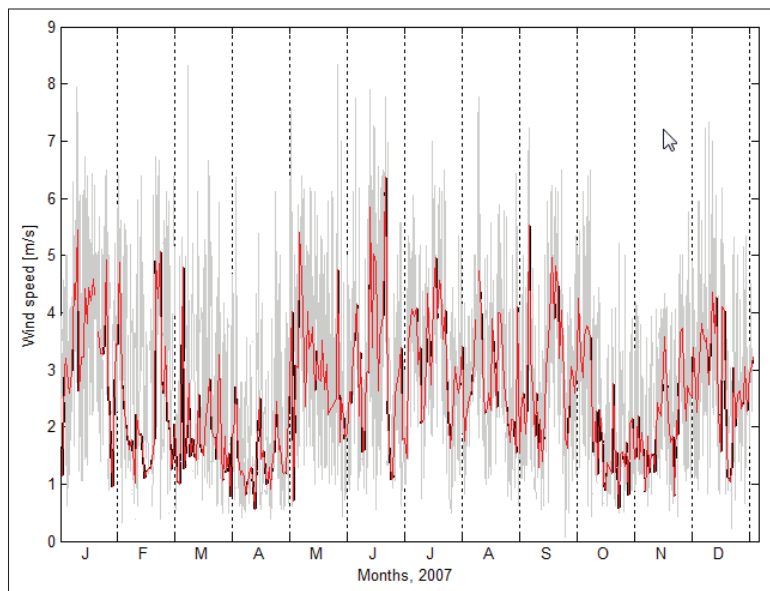

(b)

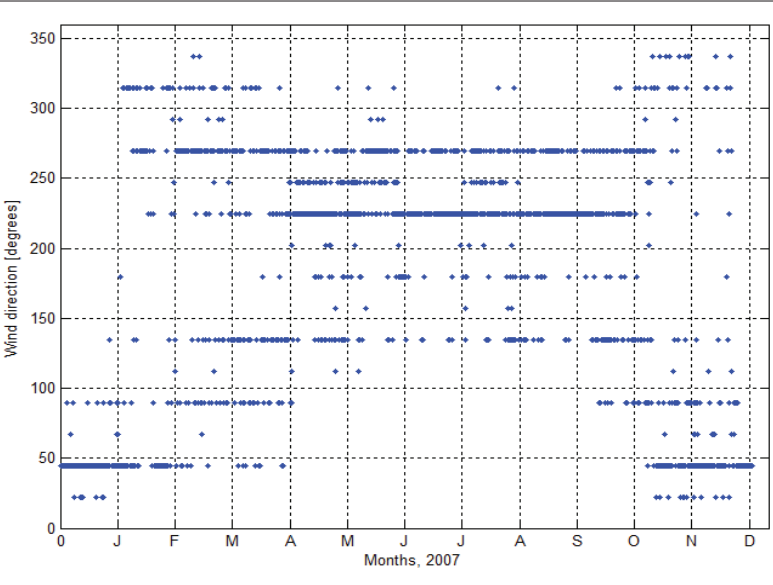

Figure 2: Wind data during January to December 2007 at Katunayaka

a). Wind speed $\left(\mathrm{ms}^{-1}\right)$. The measured data are represented by a gray line, the red line denote the daily averaged wind speed from the original; $b$ ). Wind direction

Data source: Meterological Department, Colombo

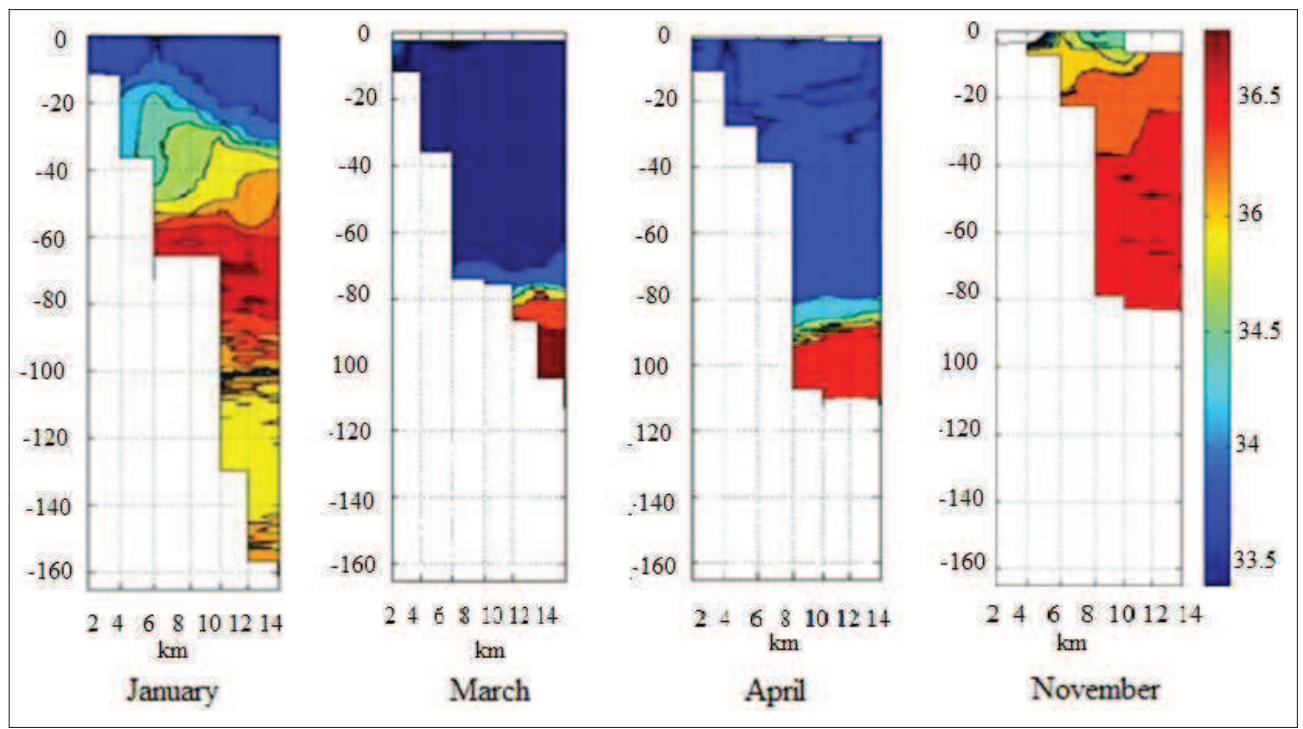

Figure 3: Vertical variation of salinity (psu) in January, March, April and November 2007 


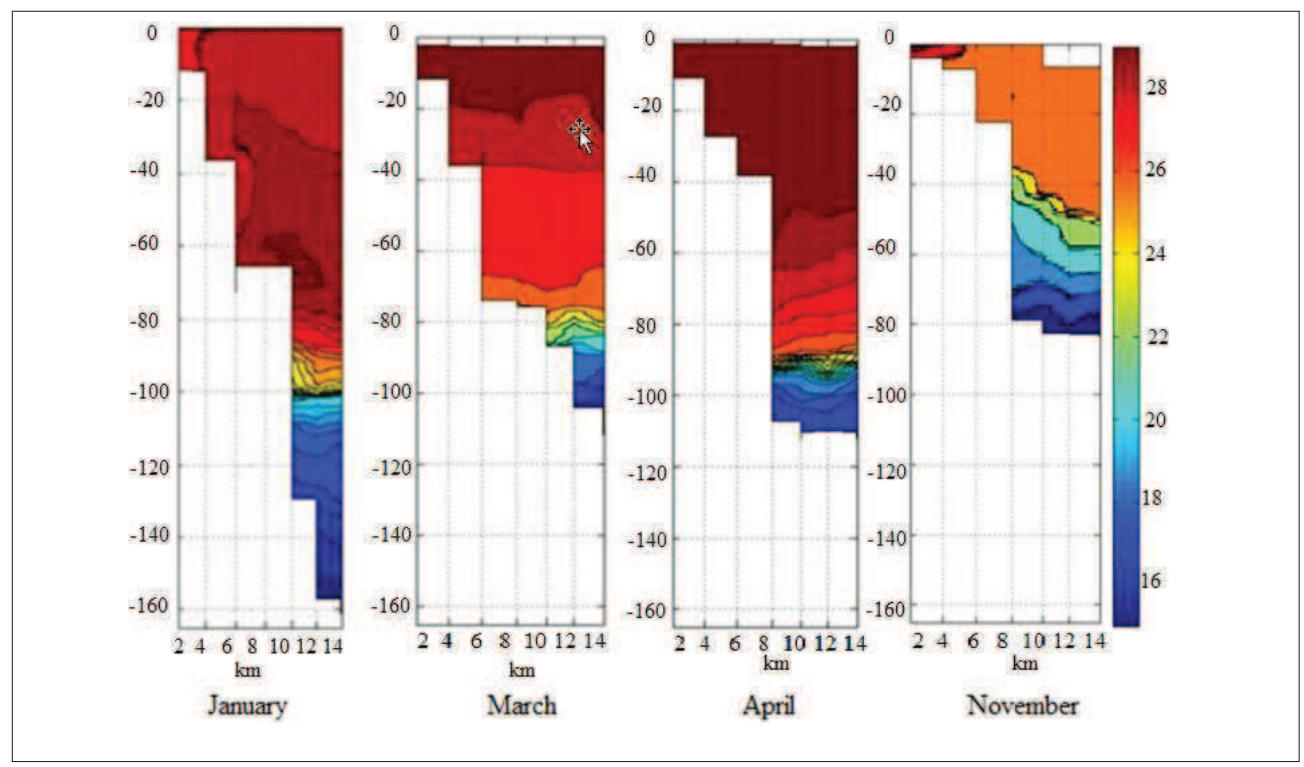

Figure 4: Vertical variation of temperature $\left({ }^{\circ} \mathrm{C}\right)$ at selected locations from January, March, April and November, 2007

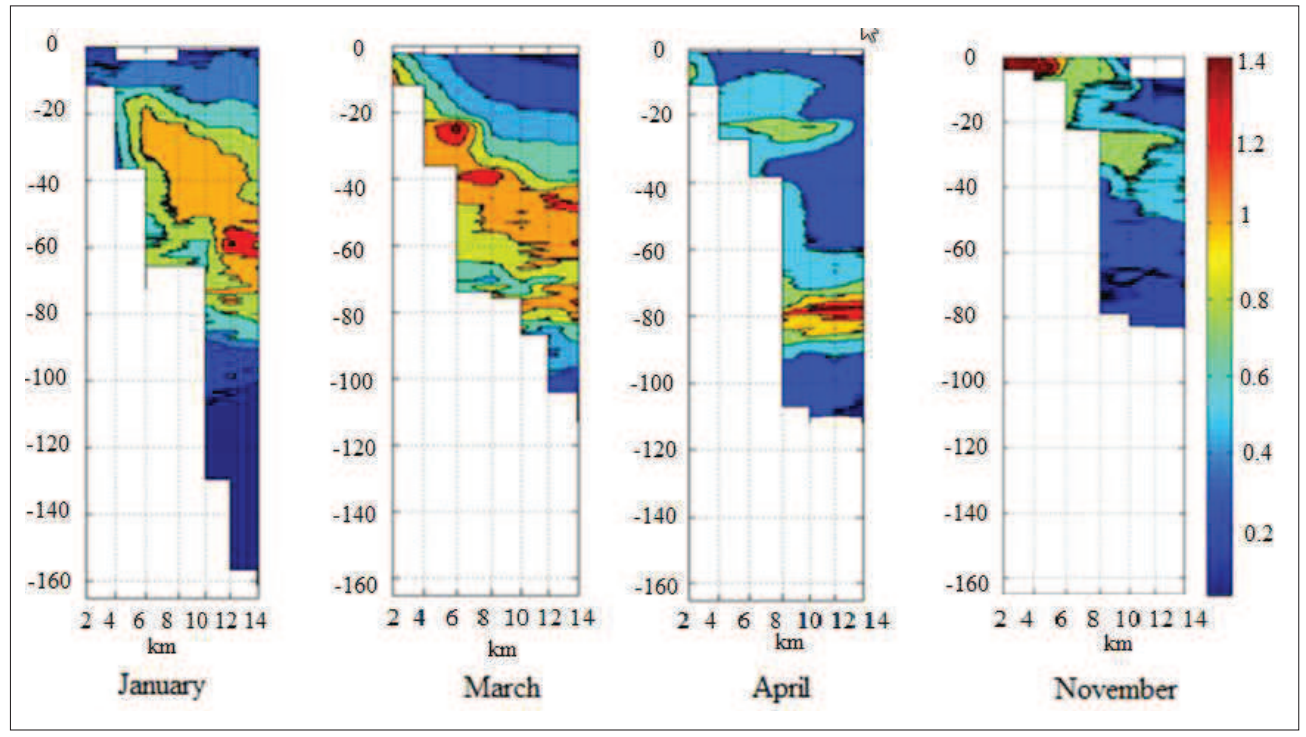

Figure 5: Vertical variation of chlorophyll- $a\left(\mathrm{mg} \mathrm{m}^{-3}\right)$ in January, March, April and November 2007

and November 2007 is illustrated in Figure 3. In January, the mixed layer depth (MLD) was shallow within the depth range of $20-30 \mathrm{~m}$ with a salinity of $33.0-33.5 \mathrm{psu}$ and deepened towards the offshore. The halocline was observed within the range of $20-60 \mathrm{~m}$ and a maximum salinity of 36.5 psu was observed within the depth range of $60-100 \mathrm{~m}$. However, the MLD in March increased to a depth of $70 \mathrm{~m}$ and a maximum salinity was observed below $90 \mathrm{~m}$. In April, the MLD deepened up to $80 \mathrm{~m}$ and showed a slight salinity decrease compared to January and March. Further, the halocline depth was recorded at 90 m. In November, a higher salinity $(36-37$ psu) was observed throughout the water column of $80 \mathrm{~m}$. During the period of study, wind field was higher compared to the other seasons. The detailed observations suggest that the thermocline was weakening during the Northeast monsoon by mixing. Vertical variation of sea surface temperature explains the salinity increase from January 
to March of the MLD. The thermocline was well defined and strong at offshore deeper locations in the study area. The highest thermocline depth was recorded in January within the depth range of $90-100 \mathrm{~m}$. A thermocline depth of $80 \mathrm{~m}$ and $90 \mathrm{~m}$ was recorded in March and April, respectively. The shallowest thermocline depth of $40-60 \mathrm{~m}$ was observed in November (Figure 3). The wind speed was very favourable for upwelling during the study period. From salinity, temperature and chlorophyll$a$ data during January, rising isotherms/ isohalines /isochl lines can be seen along the bottom coastal boundary, which is a clear indication of upwelling signals along the coastal boundary.

The vertical variation of chlorophyll- $a(\mathrm{Chl})$ at seven selected stations in January, March, April and November 2007 is shown in Figure 5. In general, the maximum chlorophyll levels could be observed in the subsurface waters depending on the mixing processes. In January the chlorophyll maximum $\left(1.2 \mathrm{mg} \mathrm{m}^{-3}\right)$ was recorded at the depth of $60 \mathrm{~m}$. Nevertheless, in January and March the chlorophyll maximum zone was higher than $1.0 \mathrm{mg} \mathrm{m}^{-3}$, which was observed within the depth range of $20-80 \mathrm{~m}$. The origin of higher chlorophyll concentration close to the coast is due to the production of land base sources. It was observed that a higher phytoplankton density dispersed within the depth range of $20-80 \mathrm{~m}$ in January to March. In April, the maximum chlorophyll level was observed at about $80 \mathrm{~m}$, which was deeper than other months. In November chlorophyll maximum disappeared at a depth range of $20-80 \mathrm{~m}$. Further, a high chlorophyll content was recorded at the surface particularly at locations close to the coast.

\section{Spatial and temporal variation of chlorophyll-a, phytoplankton and zooplankton}

\section{Chlorophyll- $a$}

One-way ANOVA revealed that the chlorophyll- $a$ concentration significantly varied among the months studied but not with the sampling locations at $\mathrm{p}=0.05$. A significantly higher chlorophyll- $a$ concentration of $0.35 \pm 0.20 \mathrm{mg} \mathrm{m}^{-3}$ was recorded in November within the upper $10-20 \mathrm{~m}$ depth than in the other months (Figure $6 a)$. However, chlorophyll- $a$ did not significantly vary among the locations (Table 1 and Figure 6b). The mean chlorophyll- $a$ concentration at the surface waters off Thalawila was $0.52 \pm 0.10 \mathrm{mg} \mathrm{m}^{-3}$ with a wide variation of $0.07-2.70 \mathrm{mg} \mathrm{m}^{-3}(\mathrm{n}=35)$.

Table 1: Summary of one-way ANOVA for distribution of chlorophyll- $a$, phytoplankton and zooplankton

\begin{tabular}{llllllll}
\hline Source & & \multicolumn{2}{c}{ Chlorophyll- $a$} & \multicolumn{2}{c}{ Phytoplankton } & \multicolumn{2}{c}{ Zooplankton } \\
\hline & df & MS & F & MS & F & MS & F \\
Month & 4 & 2.47 & $25.27 *$ & $2.12 \times 107$ & 1.02 & 14104.43 & $7.26 *$ \\
Sites & 6 & 0.30 & 0.76 & $3.73 \times 107$ & 2.16 & 2042.01 & 0.56 \\
\hline
\end{tabular}

*Significant at $\mathrm{p}=0.05$

\section{Phytoplankton}

There was no significant difference in phytoplankton abundance among the months and locations $(\mathrm{p}>0.05$; Table 1). The mean phytoplankton abundance was $3273 \pm$ 771 ind. $\mathrm{L}^{-1}$ with a variation of $300-26320$ ind. $\mathrm{L}^{-1}$ in the study area (Figures $6 \mathrm{c}$ and $6 \mathrm{~d}$ ). A total of 28 phytoplankton genera were recorded belonging to three groups identified as diatoms (24 genera), dinoflagellates (3 genera) and silicoflagellates (01 genus) in the area. Diatoms accounted for $91 \%$ of the total phytoplankton population followed by dinoflagellates, which contributed to $8 \%$ during the study. The most dominant phytoplankton genus was Rhizosolenia sp., which contributed to $21 \%$ of the total population followed by Bascillaria sp. (13\%), Navicula sp. (10\%), Coscinodiscus sp. (10\%), Chaetoceros sp.
(9\%) and Melosira sp. (8\%). Peridinium sp. was the most dominant dinoflagellates recorded in the area, which accounted for $6 \%$ of the total variation (Figure 7 ). The highest species richness was observed in November (Figure 8).

\section{Zooplankton}

Zooplankton abundance varied significantly among months but not with the studied locations (Table 1). A significantly higher zooplankton abundance of $133.80 \pm$ 27.22 ind. $\mathrm{L}^{-1}$ was found in November than that of the other months (Figure 6e). The monthly mean zooplankton abundance was $55.36 \pm 9.82$ ind. $\mathrm{L}^{-1}$ and ranged from 5 - 268 ind. $\mathrm{L}^{-1}$. Zooplankton taxa of the area was identified under 20 taxonomic groups and the most dominant group 


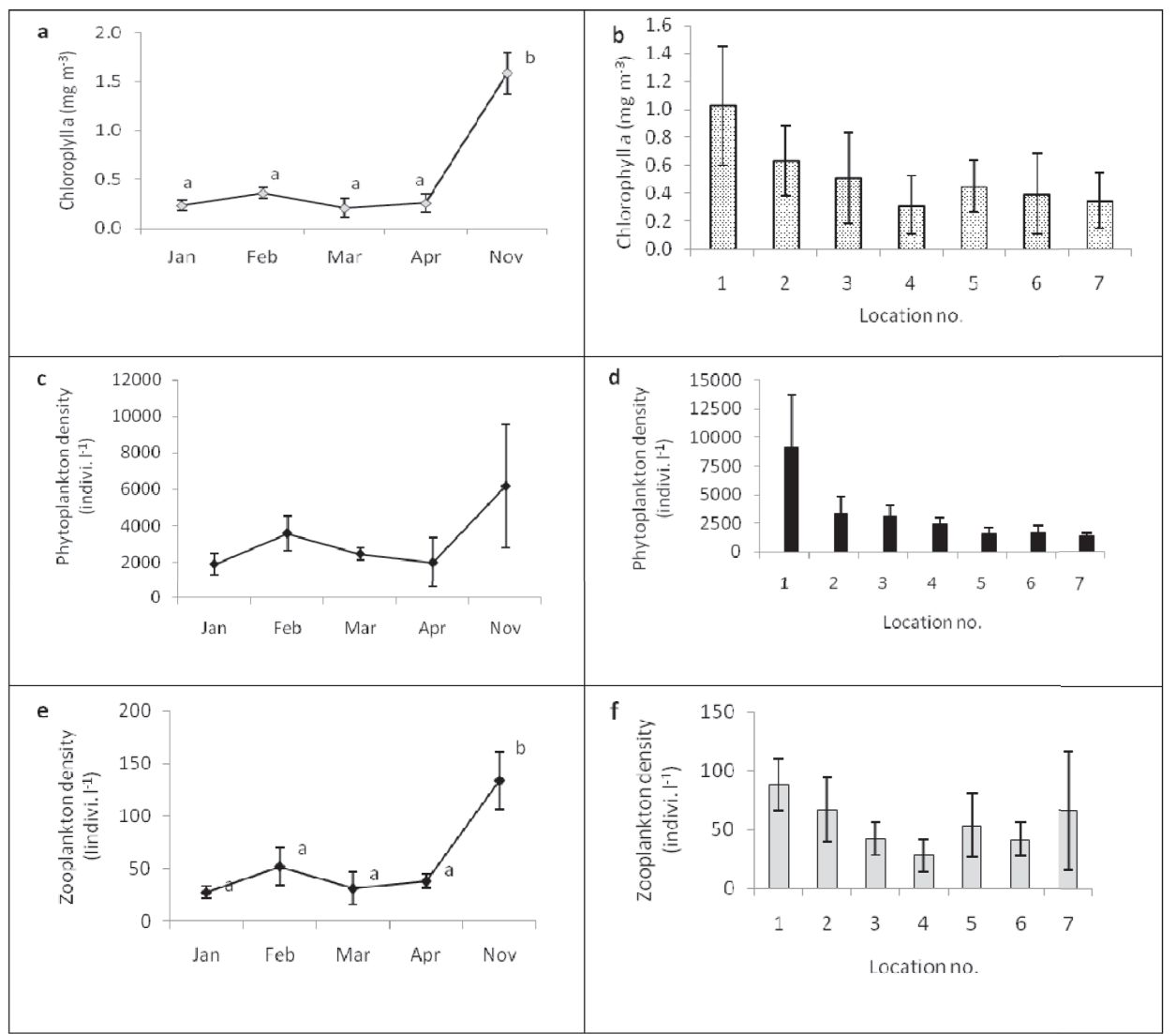

Figure 6: Variation of chlorophyll- $a$, phytoplankton and zooplankton in Thalawila sea (data point with different letters significantly vary at $\mathrm{p}=0.05$ )

a) Chlorophyll- $a$ variation among months $(\mathrm{n}=7)$; b) Chlorophyll- $a$ variation among locations; c) Phytoplankton variation among months $(\mathrm{n}=7)$; d) Phytoplankton variation among locations $(n=5)$; e) Zooplankton variation among months $(n=7)$; f) Zooplankton variation among locations $(\mathrm{n}=5)$.

Error bars on the graphs represent the standard error.

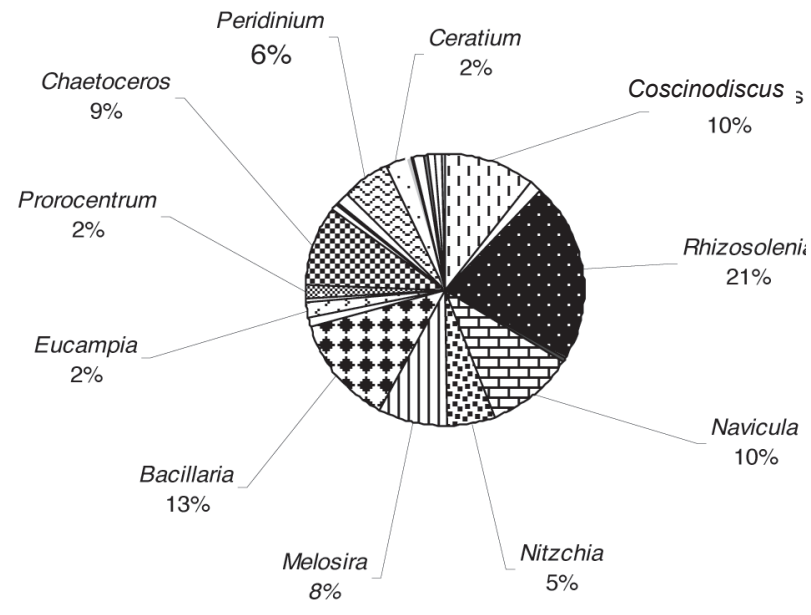

Figure 7: Overall composition of phytoplankton off Thalawila during the study period (the genera $\geq 2 \%$ are marked). 


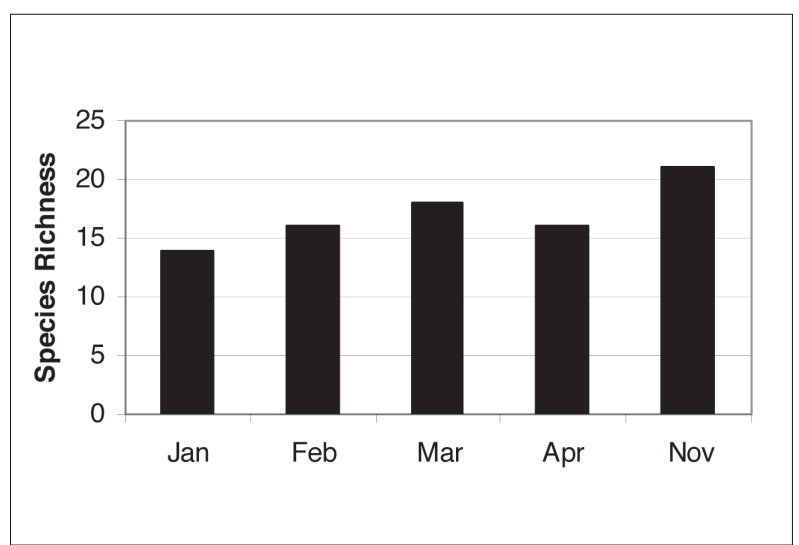

Figure 8: Species richness of phytoplankton off Thalawila during the study period in 2007

was crustacean larvae, which comprised $48.4 \%$ followed by copepods $(37.04 \%)$. Calanoid copepods comprised $33 \%$ while cheatognaths and fish eggs contributed to $3.09 \%$ and $3.1 \%$, respectively (Figure 9).

Pearson's bivariate correlation analysis revealed that chlorophyll- $a$ significantly correlated with the phytoplankton density $(\mathrm{r}=0.66)$ and zooplankton density $(\mathrm{r}=0.60)(\mathrm{p}<0.01)$. However, there was no significant correlation between the zooplankton density and the phytoplankton density.

\section{DISCUSSION}

This paper describes the vertical variation of salinity, temperature and chlorophyll, including plankton dynamics spatially and temporally in the coastal sea off Thalawila. The temporal variation was directly related to monsoon climate, which is indicated in the wind speed diagram. However, the timing of monsoon can vary by a few months depending on the onset of climatic events in the Bay of Bengal. Rao et al. (2008) observed a wind speed of $\sim 7-8 \mathrm{~ms}^{-1}$ in the area during November and February coming from the Northeast direction, which is comparatively high. It was noticed in the heat flux diagram that greater heat loss in the environment makes an upwelling condition. Similar results were observed during the present study with a wind speed of about $8 \mathrm{~ms}^{-1}$. An upwelling condition could therefore be expected during the study period compared to previous studies. Chlorophyll (Chl) profiles indicated the broader chlorophyll maximum zone, which represents an upwelling signal-intensification of $\mathrm{Chl}$ along the coastal boundary in January and March. However sub-surface narrow-band chlorophyll maximum was observed in April and it disappeared in November. The depth where

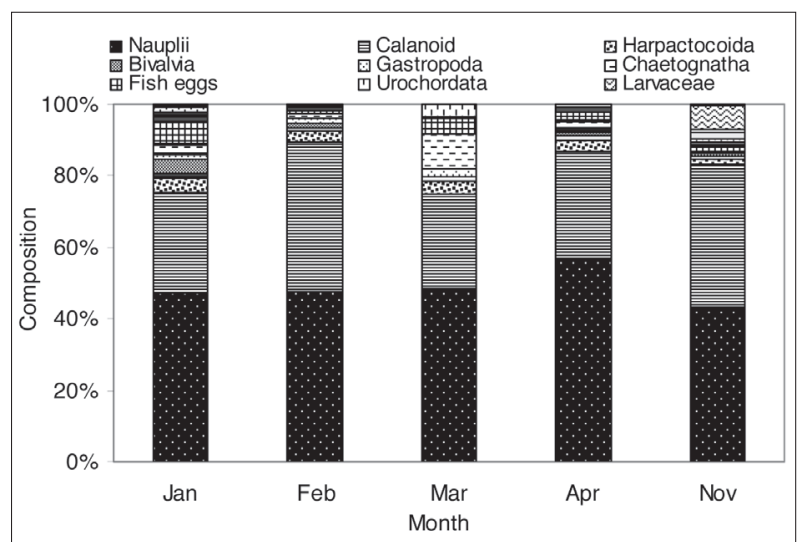

Figure 9: Composition of major zooplankton groups in Thalawila sea from January - April and November 2007.

the maximum chlorophyll- $a$ was recorded had the highest abundance of phytoplankton. Therefore, due to the higher abundance of primary producers at these depths, fish may aggregate for feeding. The shallow thermocline depth during January and March indicates that tuna might associate with shallow depth. Similar to that, in the present study a well defined and very strong thermocline has been found in the North Indian Ocean (Rao, 1964b). The low saline water originated from the Bay of Bengal has been brought by the prevailing surface currents through the Palk Strait and then the Gulf of Mannar (Rao, 1964a). However, between the equator and $5^{\circ} \mathrm{N}$ the surface salinity is moderately high and uniform (35.00 to $35.20 \mathrm{psu}$ ) representing the typical equatorial water mass.

The thickness of the thermocline layer at the North of the equator has been found to vary from $50-70 \mathrm{~m}$. During the Northeast monsoon and the inter-monsoon, the estimated successful fishing depths could be $60-90 \mathrm{~m}$ and $80 \mathrm{~m}$, respectively due to the aggregation of tuna species for favourable temperature and food availability. However the most productive month is November in terms of plankton biomass.

Fisheries data with related coordinates are important to build up a correlation between the bio-physical status with fish productivity. Northern waters within the $100 \mathrm{~m}$ isobath including the Gulf of Mannar and Palk Bay (within the area of latitudes $9{ }^{\circ} \mathrm{N}-10^{\circ} \mathrm{N}$ and longitudes $79{ }^{\circ} \mathrm{E}-80.5^{\circ} \mathrm{E}$, approximately), show high chlorophyll concentrations $\left(>0: 8 \mathrm{mg} \mathrm{m}^{-3}\right)$ throughout the year with no apparent variation from month to month (Yapa, 2000). Tang and Kawamura (2001) reported that the chlorophyll concentration was less than $3 \mathrm{mg} \mathrm{m}^{-3}$ in the southern part of the Bay of Bengal. Ocean colour studies also have 
shown that the chlorophyll concentration was higher than $2 \mathrm{mg} \mathrm{m}^{-3}$ during all the months, but the values were low $\left(<1.5 \mathrm{mg} \mathrm{m}^{-3}\right)$ in the Gulf of Mannar according to ocean colour data of IRS-P4 satellite (Sagnik \& Ramesh, 2003; Vinayachandran et al., 2004). The high chlorophyll-a content close to the coast may be due to high freshwater discharge and continuous mixing, which brings nutrients to the surface affecting high phytoplankton productivity particularly during the Northeast monsoon. However, vertical chlorophyll variation in November indicated a highly mixed environment, which may have been created by the inter-monsoonal wind effect. This may be the reason for the high chlorophyll content in surface water, which was noticed in CTD profile.

The number of phytoplankton genera reported in this study is in agreement with the data from the Gulf of Mannar and Palk Bay (Jayasiri \& Priyadarshani, 2007) and lower than the Palk Strait (Jayasiri, 2007). Further, the reported range of phytoplankton abundance in this study is lower than the Palk Strait (Jayasiri, 2007). Zooplankton abundance found in this study is consistent with the findings of Palk Strait and lower than those of the Gulf of Mannar and Palk Bay. A lower percentage of copepods $(26.5 \%)$ and crustacean nauplii $(22.5 \%)$ has been reported from the Gulf of Mannar and Palk Bay compared to the findings of the present study. However, the copepod percentage in the Palk Strait is in line with the present study. Furthermore, Jayasiri (2007) found a high coefficient of determination $\left(r^{2}=0.71\right)$ for the relationship between phytoplankton abundance and chlorophyll- $a$ concentration in the surface waters of Palk Strait.

\section{CONCLUSION}

As tuna is typically associated with the thermocline, the successful fishing depth may help tuna long liners to adjust their hooking depths during tuna fishing seasons in the Thalawila fishing ground. Fish tend to aggregate in areas with high biological productivity in terms of phytoplankton and zooplankton, which in turn affects tuna aggregation in the water column. However, a detailed study is needed along with long line fish catches to understand the correlation between environmental conditions and tuna fishing. Direct observations of tuna behaviour (collected via acoustic telemetry or electronic data-recording tags) can be combined with the information on their physiologically based environmental tolerances, forage abundance and appropriate oceanographic data. Such observational techniques will eventually provide migratory and behaviour patterns of tuna in relation to oceanic conditions in the Thalawila fishery ground, which in turn will improve the finding of tuna stocks around Sri Lanka.

\section{Acknowledgement}

Authors wish to thank all the staff members of the Oceanography Division of the National Aquatic Resources Research and Development Agency (NARA) for their invaluable assistance during field and laboratory work. Also, we would like to extend our gratitude to the reviewers of the paper for their fruitful comments which were very helpful to improve the quality of the paper.

\section{REFERENCES}

1. Azeiteiro U.M., Marques J.C. \& Re P. (2000). Zooplankton assemblages in a shallow seasonally tidal estuary in temperate Atlantic Ocean (Western Portugal: Mondego Estuary). Arquivos do Museu Bocage 3(12): 357 - 376.

2. Beers J.R. \& Stewart G.L. (1971). Microzooplankton in the plankton communities of the upper waters of the eastern tropical Pacific. Deep Sea Research 18: $861-883$.

3. Bigelow K.A., Hampton J. \& Miyabe N. (1999). Effective longline effort within the bigeye habitat and standardized CPUE. 12 $2^{\text {th }}$ Standing Committee on Tuna and BillfishSCTB12. Working Paper BET-1, 6 - 23 June, Papeete, Tahiti, French Polynesia, pp. $1-10$.

4. Block B.A., Keen J.E., Castillo B., Dewar H., Freund E.V., Marcinek D.J., Brill R.W. \& Farwell C. (1997). Environmental preferences of yellowfin tuna (Thunnus albacares) at the northern extent of its range. Marine Biology 130: 119 - 132.

DOI: http://dx.doi.org/10.1007/s002270050231

5. Boggs C.H. (1992). Depth capture time, and hooked longevity of longline-caught pelagic fish; timing bites of fish with chips. Fishery Bulletin US 90: $642-658$.

6. Cayré P. (1991). Behaviour of yellowfin tuna (Thunnus albacares) and skipjack tuna (Katsuwonus pelamis) around fish aggregating devices (FADS) in the Comoros Islands as determined by ultrasonic tagging. Aquatic Living Resources 4: $1-12$.

DOI: http://dx.doi.org/10.1051/alr/1991000

7. David V.P.C., Rowena G.W., Hugues D.C.J., Christopher P.G. \& David B.R. (2003). Occasional Publication No 15, Guide to the Coastal and Surface Zooplankton of the Southwestern Indian Ocean. Marine Biological Association of the United Kingdom, Deon, UK.

8. Dissanayake D.C.T., Samaraweera E.K.V. \& Amarasiri C. (2008). Fishery and feeding habits of yellowfin tuna (Thunnus albacares) targeted by coastal tuna longlining in the north western and north eastern coasts of Sri Lanka. Sri Lanka Journal of Aquatic Sciences 13: 1 - 21.

9. Fukami K., Watanabe A., Fujita S., Yamaoka K. \& Nishijima T. (1999). Predation on naked protozoan microzooplankton by fish larvae. Marine Ecology Progress Series 185: 285 291.

DOI: http://dx.doi.org/10.3354/meps 185285 
10. Godhantaraman N. \& Uye S. (2001). Geographical variations in abundance, biomass and trophodynamic role of microzooplankton across an inshore-offshore gradient in the Inland Sea of Japan and adjacent Pacific Ocean. Plankton Biology and Ecology 48: 19 - 27.

11. Goswami S.C. (2004). Zooplankton Methodology, Collection and Identification - a Field Manual. National Institute of Oceanography, Goa, India.

12. Guy D. (1992). The Ecology of the Fish Pond Ecosystem with Special Reference to Africa. Pergamon Press, New York, USA.

13. Jayasiri H.B. \& Priyadarshani W.N.C. (2007). Composition, abundance and spatial variation of phytoplankton and zooplankton - off Jaffna (Palk Strait). Journal of National Aquatic Resources Research and Development Agency 38: $60-76$.

14. Jayasiri H.B. (2007). Diversity and abundance of marine plankton and benthos of selected locations of Gulf of Mannar and Palk Bay, Sri Lanka. Journal of National Aquatic Resources Research and Development Agency 38: $45-59$.

15. Kitagawa T., Nakata H., Kimura S., Itoh T., Tsuji S. \& Nitta A. (2000). Effect of ambient temperature on the vertical distribution and movement of Pacific blue fin tuna Thunnus thynnus orientalis. Marine Ecology Progress Series 206: $251-260$.

DOI: http://dx.doi.org/10.3354/meps206251

16. Lorenzen C.J. (1970). Surface chlorophyll as an index of the depth, chlorophyll content, and primary productivity of the euphotic layer. Limnology and Oceanography 15: 479 -480 .

DOI: http://dx.doi.org/10.4319/lo.1970.15.3.0479

17. Neville R.A. \& Gower J.F.R. (1977). Passive remote sensing of phytoplankton via chlorophyll a fluorescence. Journal of Geophysical Research 82: 3487 - 3493. DOI: http://dx.doi.org/10.1029/JC082i024p03487

18. Newell G.E. \& Newell R.C. (1963). Marine Plankton, A Practical Guide. Hutchinson Educational Ltd., London, UK.

19. Olson D.B., Hitchcock G.L., Mariano A.J., Ashjian C.J., Peng G., Nero R.W. \& Podesta G. (1994). Life on the edge: marine life and fronts. Oceanography 7: $52-60$. DOI: http://dx.doi.org/10.5670/oceanog.1994.03

20. Parsons T.R. \& Strickland J.D.H. (1963). Discussion of spectrophotometric determination of marine-plant pigments, with revised equations for ascertaining chlorophyll a and carotenoids. Journal of Marine Research 21: 155 - 163.

21. Parsons T.R., Yoshiaki M. \& Carol M.L. (1984). A Manual of Chemical and Biological Methods for Seawater Analysis. Pergamon Press, Oxford, UK.

22. Podestá G.P., Browder J.A. \& Hoey J.J. (1993). Exploring the association between swordfish catch and thermal fronts on the U.S. longline grounds in the western North Atlantic. Continental Shelf Research 13: $252-277$.

23. Rao T.C.S. (1964a). Hydrographic Features of North Indian Ocean. Directorate of Scientific Research (Navy), Naval Headquarters, New Delhi, India.

24. Rao T.C.S. (1964b). Vertical Distribution of Temperature, Salinity and Density in Oxygen of the Bay of Bengal.
Departmental Report, India.

25. Rao R.R., Girish Kumar M.S., Ravichandran M., Gopalakrishna V.V. \& Thadathil P. (2008). A cool pool south of Indo-Sri Lanka channel and its intrusion into the Southeastern Arabian Sea during winter. Deep Sea Research I 55: 1009 - 1020.

DOI: http://dx.doi.org/10.1016/j.dsr.2008.04.006

26. Richards F.A. \& Thompson T.G. (1952). The estimation of characterization of plankton populations by pigment analyses, a spectrophotometric method for the estimation of plankton pigments. Journal of Marine Research 11: 156 $-172$.

27. Robert P. (2003). A Guide to the Marine Plankton of Southern California, $3^{\text {rd }}$ edition. UCLA Ocean GLOBE and Malibu High School, California, USA.

28. Robertson J.R. (1983). Predation by estuarine zooplankton on tintinnid ciliates. Estuarine, Coastal and Shelf Science 16: $27-36$.

29. Sagnik D. \& Ramesh P.S. (2003). Comparison of chlorophyll distributions in the northeastern Arabian Sea and southern Bay of Bengal using IRS-P4 ocean colour monitor data. Remote Sensing of Environment 85: $424-428$.

30. Shankar D., Vinayachandran P.N. \& Unnikrishnan A.S. (2002). The monsoon currents in the north Indian Ocean, progress. Oceanography 52: $63-120$.

31. Sharp G.D. (1978). Behavioral and Physiological Properties of Tunas and Their Effects on Vulnerability to Fishing Gear. Academic Press, New York, USA.

32. Stoecker D.K. \& Capuzzo J.M. (1990). Predation on protozoa: its importance to zooplankton. Journal of Plankton Research 12: 891 - 908.

DOI: http://dx.doi.org/10.1093/plankt/12.5.891

33. Sund P.N., Blackburn M. \& Williams F. (1981). Tunas and their environment in the Pacific Ocean: a review. Oceanography and Marine Biology 19: 443 - 512.

34. Tang D.L. \& Kawamura H. (2001). Long-term time series satellite ocean color products on the Asian waters. Proceedings of the $11^{\text {th }}$ Pacific Asian Marginal Seas/Japan East China Seas Study (PAMS/ JECSS) Workshop, pp. 49 52. Hanrimwon Publishing, Seoul, South Korea.

35. Todd C.D., Laverack M.S. \& Boxshall G.A. (1991). Coastal Marine Zooplankton, A Practical Manual for Students. Cambridge University Press, New York, USA.

36. Verlencar X.N. \& Somshekar D. (2004). Phytoplankton Identification Manual. National Institute of Oceanography, Goa, India.

37. Vinayachandran P.N., Chauhan P., Mohan M. \& Nayak S. (2004). Biological response of the sea around Sri Lanka to summer monsoon. Geophysical Research Letters 31(1): L01302

DOI: http://dx.doi.org/10.1029/2003GL018533

38. www.seabird.com/, access date 08/07/2013

39. Wyrtiki K. (1973). Physical Oceanography of the Indian Ocean: The Biology of the Indian Ocean. Springer Verlag, Berlin, Germany.

40. Yapa K.K.A.S. (2000). Seasonal variability of sea surface chlorophyll-a of waters around Sri Lanka. Proceedings of the Indian Academy of Sciences-Earth and Planetary Sciences 109: $427-432$. 